\title{
Introduction
}

\section{Colin Robinson}

This book contains revised versions of papers presented in the Beesley Lectures in the autumn of 2004, the fourteenth consecutive year of the series which was founded in 1991 by the late Professor Michael Beesley and arranged by him until his death in 1999. His intention was that it should be a forum for discussing utility regulation and competition policy, involving both utility regulators and other commentators. The series is organised by the London Business School and the Institute of Economic Affairs, with both of which Michael was closely associated, the first as a Founding Professor and the second as a Managing Trustee. As usual, the fourteenth series ranged widely in terms of the issues considered and the countries concerned.

The opening chapter is by Tom Winsor who was Rail Regulator and International Rail Regulator from 1999 to 2004. Winsor is highly critical of government policy towards the railways during his period of office. He emphasises that he had to deal with 'some severe assaults on the independence and jurisdiction of the ORR' (Office of Rail Regulation) during his period of office and that there was a 'significant degree of political interference with Railtrack, almost all of it unwarranted'. In his analysis of the 2004 White Paper on the railways, he points out some problems - for instance, the difficulties of taking the functions of the Strategic Rail Authority (SRA) into the Department of Transport and moving rail safety obligations from the Health and Safety Executive to the ORR. Nevertheless, he concludes that his successors have some advantages, particularly now that the SRA no longer exists. They have '(at present) firm political support, significantly better asset knowledge and maintenance and renewal policies and practices on the part of Network Rail'.

Professor Stephen Glaister, of Imperial College, in his comments, ${ }^{*}$ argues that the White Paper is a 'terribly weak document'. As in the case of the 1993 Railways Act and the preceding White Paper, ministers were unwilling or unable to write down clearly in advance what they wanted. One outcome of the 2004 White Paper will be a railway more under the direct control of central 
that adds little to the security of the nation's energy supplies'. Simpson argues that, instead of the government's 'picking winners' procedure among technologies, it would be better to employ a carbon tax or a carbon trading scheme to reduce the consumption of carbon-intensive energy: market prices would adjust to reflect the environmental damage of carbon emissions and the cost of achieving environmental goals would become more transparent. The government's renewables (and energy efficiency) schemes would then become largely redundant. Simpson ends by saying that wind energy will probably play some part in Britain's future energy supply but it should be done as efficiently as possible.

Alistair Buchanan, Chief Executive of the Office of Gas and Electricity Markets (Ofgem), in his comments, explains the role of Ofgem in the renewables programme. It acts as administrator for the government's Renewables Obligation Certificate (ROC) scheme and it facilitates network development in onshore transmission and distribution and in offshore pipelines. Buchanan also points out the constraints that bind Ofgem. Like other independent regulators, it must not 'cross the boundary of policy at the expense of customers'; it must be accountable for its costs; and, according to its social and environmental guidance from government, any significant financial impact must be dealt with by government.

In Chapter 4, Sir Christopher Bellamy, Chairman of the Competition Appeal Tribunal (CAT), discusses four broad roles of the CAT - to ensure that the system is seen to be fair, to get the law right (given the 'considerable amounts of "grey area"'), to aid transparency and visibility, and to produce dialogue so that the system adapts and develops. In fulfilling its roles, the Tribunal uses working methods that represent modern best practice, including extensive written argument, early disclosure, strict time limits, site visits and extensive use of its website. Bellamy raises some questions for the future that need to be addressed. Among them are whether a 'competition culture' has really taken root in Britain; the importance of regional and local enforcement of competition policy; the benefits of a 'reasonable flow of enforcement decisions'; and the issue of increasing deterrence. Finally, Bellamy points to the need to 'forge a central core of relatively simple rules or presumptions ... capable of being applied by business people or nonspecialist advisors in a way that makes the law understandable, accessible and reasonably certain, as well as enforceable at reasonable cost'.

Professor George Yarrow, of RPI Europe, begins his comments on Bellamy's chapter by emphasising the importance of judicial supervision of the use of executive power: "many of the most important occurrences of conspiracies against consumers, of abuses of power, and of undue concentration of power are to be found within government'. Furthermore, in his view, judges perform ayital function in putting 90 bstactes in the 
economic context so that, for instance, rather than prohibiting some form of behaviour, the economic circumstances in which it takes place should be examined. European law on predatory pricing shows that 'practical administrability and economic grounding can go together'. What is now required is to confront the 'fundamental question of what is harm to competition, and to develop practical approaches to other kinds of abuse that are similarly grounded in economic principle'.

In Chapter 7, Dr John Fingleton, Chairman of the Irish Competition Authority when the lecture was given, discusses the role of economics in merger reviews. Economic analysis has, he says, contributed both to the formulation of merger law and to the investigation of economic effects in merger cases. As regards the 'why' of merger policy, the competition test for mergers has become the norm in many countries because of the influence of economics: 'the critical factor is the relationship between competition and productivity growth'. Moreover, in most jurisdictions, economic effects analysis is now common and well established, even if questions remain about standards of proof and evidence. Competition authorities should advocate 'the use of competition tests implemented with effects-based analysis', says Fingleton. In the long term, 'legal certainty is enormously enhanced if merger decisions reflect sound economic analysis'. Solid economic foundations are particularly important 'in a world where merger decisions on the same or similar transactions are taken by different institutions in different countries'.

Professor Leonard Waverman, in his comments, raises the question of whether a consumer surplus or a total surplus test should be used in implementing merger policy. He points out that, despite the efforts to promote convergence in merger policy among countries, which Fingleton mentions, many differences remain even within the EU. Waverman argues that, since there is little evidence that competition authorities make the correct decisions in merger cases, it may not matter if it is difficult to block mergers ex ante. More important is ex post analysis to determine whether mergers result in increases in consumer surplus or total surplus. He ends by suggesting that economists may find the courts less and less willing to tolerate 'on the one hand' and 'on the other hand' statements by expert witnesses.

Philip Fletcher, Director-General of Water Services, originally commented on a paper in the series - on economies of scale and productivity growth in water - that it has unfortunately not been possible to publish. But, since his remarks on mergers in the water industry and on the place of comparative competition are of interest in themselves, they are reproduced in slightly modified form as a contribution in its own right. He begins by explaining why the regional water authorities were not broken up before

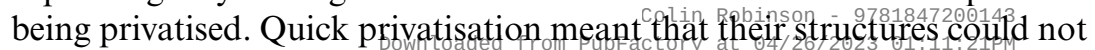


be changed: structural reorganisation would have meant that there would have been no 'evidence or data to float these companies in the market'. Fletcher points out that although academic commentators tend to argue as though there have been no mergers in water, there have been plenty of takeovers as well as substantial restructuring. He stresses the importance of having 22 companies to compare with each other. In the 2004 price review, 'comparative competition was a crucial and essential part of the regulatory tool kit. Without it the companies could call almost all the shots'.

The final chapter in the book is on privatisation and regulation in developing countries, by Professors David Parker of Cranfield University and Colin Kirkpatrick of the University of Manchester. It was presented in the series by David Parker. The authors argue that insufficient attention has been devoted to the design of institutional structures and regulatory instruments in infrastructure privatisations in the developing world. One problem is the lack of regulatory capacity: for example, the shortage of trained personnel, the absence of sound laws and uncertainty about law enforcement. Regulatory impact assessments (RIAs) might, say the authors, help to improve regulatory capacity. Another issue is whether price cap regulation is suitable in the circumstances of many developing countries - for example, serious information asymmetry, weak regulatory governance and problems in creating effective regulatory incentives. Some survey evidence suggests that there may be advantages in rate of return regulation. Parker and Kirkpatrick conclude that uninformed transfer of regulatory systems has taken place and that more research is required to investigate appropriate forms of regulation for developing countries.

Commenting, Professor Colin Robinson, University of Surrey, agrees with the authors' emphasis on the importance of regulatory institutions and the danger of importing inappropriate regulatory systems from developed countries. He has doubts, however, whether the use of RIAs will bring about much improvement. On price cap regulation, he argues that it is not only in the developing world that price cap regulation has gone far beyond what its originators had intended. He sketches the circumstances in which price caps are appropriate, which normally include separation of the network from the rest of a utility. If these conditions cannot be met, it may indeed be that price caps will not work well, though it is difficult to see that rate of return regulation would be any better. Regulatory systems, once entrenched, tend to grow out of control, Robinson argues. 